\title{
ACPD
}

13, 21573-21608, 2013

\section{Primary productivity and its variability in the equatorial South China Sea during the northeast monsoon}

\author{
S. H. Ooi ${ }^{1}$, A. A. Samah ${ }^{1,2}$, and P. Braesicke ${ }^{3}$
}

${ }^{1}$ National Antarctic Research Center, Institute of Postgraduate Studies, University of Malaya, 50603 Kuala Lumpur, Malaysia

${ }^{2}$ Institute of Ocean and Earth Sciences, Institute of Postgraduate Studies, University of Malaya, 50603 Kuala Lumpur, Malaysia

${ }^{3}$ NCAS/University of Cambridge, Chemistry Department, Cambridge, UK

Received: 24 July 2013 - Accepted: 16 August 2013 - Published: 21 August 2013

Correspondence to: S. H. Ooi (axl419@yahoo.com)

Published by Copernicus Publications on behalf of the European Geosciences Union.

Primary productivity and its variability in the equatorial SCS

S. H. Ooi et al.

\section{Title Page}

Abstract 


\section{Abstract}

Near coastal areas of the equatorial South China Sea (SCS) are one of the world's regions with highest primary productivity (phytoplankton growth). Concentrations of phytoplankton in the SCS depend significantly on atmospheric forcings and the oceanic 5 state, in particular during the northeast (winter) monsoon season from November to March. Aided by new ocean-observing satellite data, we present a climatological overview of recent surface atmospheric and oceanic features in the equatorial SCS during the northeast monsoon to identify the dominant air-sea processes influencing and modulating the primary productivity of the region. Measured chlorophyll a concentrations are used as a proxy for phytoplankton amounts and the spatial and temporal variations are characterized according to meteorological conditions. Converging northeasterly surface winds support high chlorophyll a concentrations along East Malaysia's coastline in conjunction with a continual nutrient supply from the bottom of the continental shelf by vertical mixing. The mixing can be enhanced due to increased turbulence by wind-generated high waves when they approach shallow water from the deep basin during strong cold surges and monsoon disturbances. Intraseasonal variability during the winter monsoon is characterized by a coastal increase of chlorophyll a starting in November and peaking in January. A general decrease is observed in March. Interannual variability of chlorophyll a concentrations is influenced by ENSO (due to the known modulation of cold surge occurrences), with decreases during El Niño and increases during La Niña in early winter along the shore of East Malaysia. As an example, we discuss an enhanced phytoplankton growth event that occurred due to a typical cold surge-induced Borneo vortex event in January 2010.

\section{Introduction}

25 The South China Sea (SCS) lies between the equator and $23^{\circ} \mathrm{N}$ and extends from 99 to $121^{\circ} \mathrm{E}$ (Fig. 1). It is a marginal sea of the Pacific Ocean with a total area of around
ACPD

13, 21573-21608, 2013

Primary productivity and its variability in the equatorial SCS

S. H. Ooi et al.

Title Page
Abstract

Conclusions

Tables

14

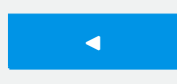

Back
Introduction

References

Figures

DI

Close
Full Screen / Esc

Printer-friendly Version

Interactive Discussion 
$3500000 \mathrm{~km}^{2}$. It has wide continental shelves to the north and south, steep slopes on the east and west sides, and a near elliptical shaped central basin extending to over $4000 \mathrm{~m}$ deep. The basin is connected to the open ocean through several passages between the surrounding landmasses and islands, but exchanges water most efficiently 5 with the western North Pacific through the Luzon Strait. One-third of the world's shipping is transiting through the SCS, and large oil and gas reserves are likely underneath its seabed. This commercially very important sea holds one third of the entire world's marine biodiversity, thereby making it a substantial part of the global ecosystem (available at http://en.wikipedia.org/wiki/South_China_Sea).

10 The equatorial part of the SCS (defined here as the area between $8^{\circ} \mathrm{N}$ and the equator) is strongly affected by severe weather during the northeast monsoon from November to March (Lim and Azizan, 2004). During the monsoon season cold northeasterly winds blow over the SCS as a result of the migratory Siberian high pressure system. Cold air over the SCS is maintained by radiative cooling and continuous advection of air masses from Siberia. In response to the intensifications of the Siberian high pressure systems and its subsequent southward movement, the northeast-to-southwest oriented strong wind bands of so-called "cold surges" (a specific regional definition with respect to the equatorial South China Sea) are positioned over the central SCS. The wind bands, interacting with the near equatorial trough, trigger the evolution of organised mesoscale convective cloud clusters, resulting in high ocean waves and torrential rains over the equatorial South China Sea. Malaysia is located on the southern side of the SCS and major parts of its coastline are exposed to both the atmospheric and oceanic impacts of the monsoon.

The broad and shallow Sunda Shelf lies off the east coast of Peninsular Malaysia 25 and narrows towards coastal Sabah (Fig. 1). Usually, a depth of $200 \mathrm{~m}$ corresponds to the edge of the continental shelf where the transition between shallow and deep waters occurs. The near coastal areas of the continental shelves tend to have high concentrations of chlorophyll and phytoplankton (Stewart, 2008). In low latitudes, nutrients are efficiently recycled in shallow, well-mixed shelf waters. Also, nutrients supplied

ACPD

13, 21573-21608, 2013

Primary productivity and its variability in the equatorial SCS

S. H. Ooi et al.

Title Page
Abstract

Conclusions

Tables

14

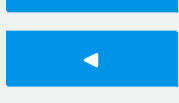

Back
Introduction

References

Figures

- I

$>$

Close
Full Screen / Esc

Printer-friendly Version

Interactive Discussion 
by run-off from land are major sources of enhanced productivity together with high light levels in shallow coastal waters. Phytoplankton provides food for a tremendous variety of organisms, including zooplankton, shellfish and small fish. These animals, in turn, provide food for other animals, including crabs, starfish, fish, marine birds, marine 5 mammals, and humans.

The equatorial South China Sea may have abundant sources of biogenic trace gases, produced and released from phytoplankton biomass in both coastal waters and the open sea. It is known that short-lived halocarbons are transported to the upper troposphere and lower stratosphere, potentially contributing to stratospheric ozone de10 pletion. The availability of source gases and the efficiency of transport from the tropospheric boundary layer into the lowermost stratosphere determine the overall impact on the stratospheric ozone budget (Pyle et al., 2011). With respect to the efficiency of transport, a case study of a cold surge-induced Borneo vortex event in January 2010 (Ooi et al., 2011 and Braesicke et al., 2012) shows that the equatorward (i.e. south of the near-equatorial trough) convective clusters related to the vortex are potentially efficient/fast transport routes to the lowermost stratosphere. This equatorward sector encompasses off-coast (with relatively high sea surface temperature) and coastal land areas of Sarawak and Sabah. The combination of converging surface winds, enhanced sea surface temperature and intense afternoon heating, especially over land, causes vigorous and deep convection events (cumulonimbus tops as high as 60000 feet $(\sim 18 \mathrm{~km})$ have once been reported by a pilot near Kota Bahru at the northeastern coast of Peninsular Malaysia). Potential vorticity analysis (Fig. 13b in Ooi et al., 2011) shows distinct and deep incursions of lower stratospheric air into the upper troposphere and vice versa in the sector, thus indicating that deep convection forms a sporadic gateway for tropospheric air to enter the lowermost stratosphere.

Recently new data sets of ocean colour (oc) have become available (Suhung Shen et al., 2007). This data does not allow the precise quantification of the amount of primary productivity but can be used to discuss relative changes through a season or between different years. After introducing the data sources and methods (Sect. 2), we present
ACPD

13, 21573-21608, 2013

Primary productivity and its variability in the equatorial SCS

S. H. Ooi et al.

Title Page

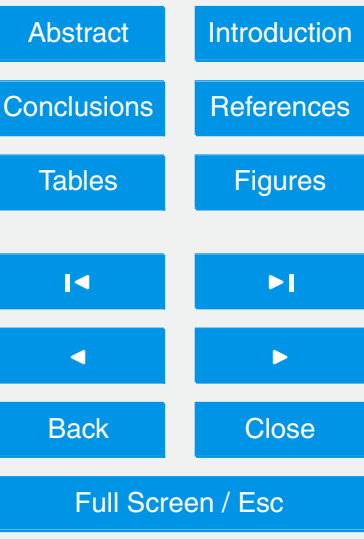

Printer-friendly Version

Interactive Discussion 
the mean state (climatological features) during the northeast monsoon, particularly of the wind-generated waves and wind-induced sea surface currents, and chlorophyll $a$ concentrations (Sect. 3). We continue discussing the intraseasonal variability of the mentioned quantities and analyze how the EI Niño Southern Oscillation (ENSO) phe5 nomenon, the dominant factor of interannual variability, modulates the mean states (Sect. 4). We conclude with a case study showing the impact of a Borneo vortex event on phytoplankton growth (Sect. 5). We summarize our findings in Sect. 6.

\section{Data and methods}

Surface reanalysis data ( $10 \mathrm{~m}$ wind, mean sea level pressure, wave direction, period, 10 significant height as well as swell) at 00 UTC from the European Centre for MediumRange Weather Forecasts (ECMWF) are used. These so-called ERA-Interim (Dee et al., 2011) data have a spatial resolution of $0.75^{\circ} \times 0.75^{\circ}$ in latitude and longitude and are available at 6 hourly intervals. We complement the reanalysis data with a wide range of satellite observations. We use monthly mean products of SeaWiFS (Sea15 viewing Wide Field-of-view Sensor, $9 \mathrm{~km}$ chlorophyll a concentrations) and MODIS (Moderate Resolution Imaging Spectroradiometer, $9 \mathrm{~km}$ sea surface temperatures, available only from 2002 onwards). Data was obtained from Giovanni (the Goddard Earth Sciences Data and Information Services Center (GES-DISC) Interactive Online Visualization and Analysis Infrastructure). For January 2010 daily products of SeaWiFs chlorophyll a concentrations and MODIS sea surface temperatures from Ocean Color web are utilized. Furthermore, OSCAR (Ocean Surface Current Analysis - Real time) data are used.

The climatological base periods are chosen as 2000-2008 for November and December and 2001-2009 for January, February and March. The region we analyze ex-

\section{ACPD}

13, 21573-21608, 2013

Primary productivity and its variability in the equatorial SCS

S. H. Ooi et al.

Title Page

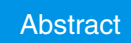

Introduction

Conclusions

Tables

References

\section{Figures}

$>1$

14

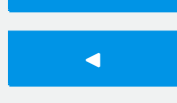

Back

Full Screen / Esc

Printer-friendly Version

Interactive Discussion phyll a concentrations we reduce the map area coverage to extend only from 98 to $126^{\circ} \mathrm{E}$ and from the Equator to $15^{\circ} \mathrm{N}$ so as to emphasize the differences/anomalies. 
We show monthly mean data averaged over the years 2000 to 2009 . For the meteorological variables we chose the 00:00 UTC data for averaging when convective cloud clusters are fully developed due to cloud-top radiational cooling (Gray, 1977) and the interaction of a mature land breeze with the prevailing surface winds.

In most of the satellite-derived data, a "rainbow" palette is utilized for the analysed figures. Higher values of the data parameter are expressed in warmer colors (i.e. red and orange), low values are in cooler colors (blue and purple), and intermediate values are greens and yellows. The white areas in any plot of satellite data indicate that data is not available due to clouds. For the interpretation of satellite-derived data, it is useful 10 to bear in mind that single-image scenes may show more details of spatial distributions (including more pronounced extremes) but monthly averaged images will be able to capture a tendency including intraseasonal and interannual changes (DanLing Tang et al., 2004).

With the exception of chlorophyll a concentrations, we show the following months: 15 November (onset of the winter monsoon season), January (peak monsoon month) and March (end of the monsoon season) to describe the climatological features and seasonal progression.

In this paper we use wind stress to assess upwelling due to Ekman transport. Wind stress $\left(\mathrm{Nm}^{-2}\right.$ or Pascals), is the horizontal force exerted on the sea surface, thus the vertical transfer of horizontal momentum from the atmosphere to the ocean. We compute it using the conventional bulk formula

$\tau=\rho \cdot C_{d} \cdot W^{2}$

where $\rho=$ air density $=1.22 \mathrm{~kg} \mathrm{~m}^{-3}, C_{\mathrm{d}}=$ neutral $10 \mathrm{~m}$ drag coefficient $=1.2 \times 10^{-3}$, and $W=$ wind speed at $10 \mathrm{~m}$ above the sea $\left(\mathrm{m} \mathrm{s}^{-1}\right)$.

25 When wind blows over the sea surface it induces a current by friction that is deviated by the Coriolis force to the right of the wind direction (in the Northern Hemisphere). At the surface, the current moves at an angle of about $45^{\circ}$ relative to the wind direction. The net transport of water through the entire wind-driven water column is approximately 21578

\section{ACPD}

13, 21573-21608, 2013

Primary productivity and its variability in the equatorial SCS

S. H. Ooi et al.

Title Page

Abstract

Introduction

Conclusions

References

Tables

Figures

14

$\rightarrow$

4

Back

Close

Full Screen / Esc

Printer-friendly Version

Interactive Discussion
$>$

interastion

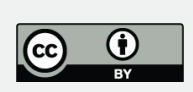


$90^{\circ}$ to the direction of the wind. This movement of water is called Ekman transport or Ekman flow. Winds and currents thus combine to bring cold nutrient-rich water from below the thermocline to the surface, especially near the coast where the upwelling flow is strongest. However, on the continental shelf, currents move at an angle to the 5 wind that is substantially less than $45^{\circ}$ and the entire wind-driven water column is typically much less than $90^{\circ}$ to the wind direction. In continental shelf shallow water the relative effect of Ekman transport depends on the depth of the water relative to the so-called Ekman depth which depends primarily upon latitude and wind speed. Lower latitudes result in a weaker Coriolis force and, consequently, greater Ekman depths.

10 Higher wind speeds also lead to a greater Ekman depth. For example, wind speeds of 5,10 and $20 \mathrm{~m} \mathrm{~s}^{-1}$ around $15^{\circ} \mathrm{N}$ correspond to Ekman depth of 75, 150 and $300 \mathrm{~m}$, respectively. When the water depth equals about one half of the Ekman depth, the surface current is already rotated by about $45^{\circ}$ relative to the wind direction, but the mean water motion through the Ekman layer is still closer to the wind direction than 15 in deep water: about $70^{\circ}$ as opposed to $90^{\circ}$. As the water gets shallower relative to the Ekman depth, the current direction approaches the wind direction and the current speed decreases due to bottom friction (Stewart, 2008). This supports the absence of upwelling in the equatorial SCS (because $\tau$ is small) and therefore the chlorophyll $a$ production here is due to other processes.

\section{ACPD}

13, 21573-21608, 2013

Primary productivity and its variability in the equatorial SCS

S. H. Ooi et al.

Title Page

\section{Climatological features}

\subsection{Mean sea level pressure and surface wind}

The dominant surface feature during the winter or northeast monsoon season (November to March) is the Siberian high (Zhang et al., 1997). This pressure system covers a large part of the Asian continent and produces a northeasterly flow over East Asia.

25 The left column of Fig. 2 shows the mean sea level pressure (mslp, shaded). From November (Fig. 2a, left) to December MSLP increases over East Asia, leading to an

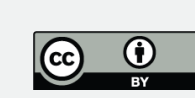


intensification of both the east-west and north-south pressure gradients. In particular, the intensification of the north-south pressure gradient due to an intensified and southward-moving Siberian high causes northeasterly cold surges to spread southwards over the SCS. The near surface winds show a maximum (20-30 knots) off the 5 Vietnam coast aligned in the northeast-southwest direction pushing southwards towards the near equatorial trough at around $3^{\circ} \mathrm{N}$. Peninsular Malaysia, being at the downstream end of this strong jet, is fully exposed to the monsoon while northeasterly winds are weaker in Sabah and Sarawak. By December, high pressure is already established in the north over China and pressure increases further towards January.

Close to the equator, the near equatorial trough (low pressure system) develops fully during January (Fig. 2b, left) and February. However, during January and February, part of the near equatorial trough over Peninsular Malaysia weakens, with the exception of the part along East Malaysia where Borneo vortices, the main triggers of heavy rainfall, develop upon initiation of cold surges and are embedded within it. Owing to the discontinuity in surface roughness at coastlines, northwesterly and northeasterly flows aid an increase of precipitation and turbulent mixing over Sabah and Sarawak due to frictional convergence (Roeloffzen et al., 1985; Ooi et al., 2011), especially in the presence of vortices. The north-south pressure gradient weakens in late winter, from February to March (Fig. 2c, left). By March, the monsoon has weakened considerably

\subsection{Sea surface temperature}

The right column of Fig. 2 shows monthly mean sea surface temperature (SST). A strong gradient exists north of $15^{\circ} \mathrm{N}$ in November over the South China Sea (Fig. 2a, right). Cold waters from the East China Sea and the Northwest Pacific are advected onwards. This leads to a transport of cooler water southwards, mainly along the Vietnam coast and towards Peninsular Malaysia (Wrytki, 1961). As the coastal waters of East Malaysia and the Philippines are more influenced by currents that flow from the

\section{ACPD}

13, 21573-21608, 2013

Primary productivity and its variability in the equatorial SCS

S. H. Ooi et al.

Title Page

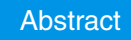

Introduction

Conclusions

References

Tables

Figures

14

-I

4

Back

Close

Full Screen / Esc

Printer-friendly Version

Interactive Discussion
$>$

niscussion

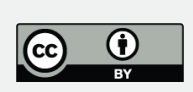


Pacific region through the various inland seas including Sulu and Celebes Seas, the SST is higher off the coast of Borneo. This causes a northwest-southeast aligned SST gradient between Vietnam and East Malaysia across the equatorial South China Sea, which intensifies towards its seasonal peak in January (Fig. 2b, right). This is clearly 5 visible in Fig. $2 \mathrm{~b}$ as a dark green band indicating a temperature range of $24-25^{\circ} \mathrm{C}$, reaching as far south as $4^{\circ} \mathrm{N}$. The near equatorial trough (Fig. $2 \mathrm{~b}$, left) lies along the coastal waters of Sabah and Sarawak. The presence of a strong SST gradient over the equatorial South China Sea influences the seasonal convection patterns and thereby the rainfall distributions particularly over Peninsular Malaysia and East Malaysia.

\subsection{Sea surface wind stress}

Figure 3 shows the climatological mean surface wind stress vectors (arrows) and magnitude (shaded) for the SCS in November, January and March, respectively. A northeasterly wind stress maximum of greater than $0.08 \mathrm{Nm}^{-2}$ begins to appear in November and moves southwestwards to the equatorial SCS to as far south as $5^{\circ} \mathrm{N}$ in January. 15 Near coastal areas of East Malaysia show small or negligible wind stress. The wind stress maximum retreats northeastward and weakens in February. By March, only very weak wind stress magnitudes (less than $0.06 \mathrm{Nm}^{-2}$ ) exist throughout the SCS.

From the magnitude and orientation of wind stress vectors two seasonal upwelling regions in the South China Sea can clearly be identified, namely, $19-21^{\circ} \mathrm{N}, 118-120^{\circ} \mathrm{E}$ 20 (maximum stress cores in November and December, off the northwestern coast of Luzon Island) and $8-11^{\circ} \mathrm{N}, 109-111^{\circ} \mathrm{E}$ (maximum stress cores in December and January, off the southeastern coast of Vietnam). These have also been noted by Liu et al. (2002). To the southeast of Vietnam a steep shelf break along $108^{\circ} \mathrm{E}$ (IPRC, 2005) enables cyclonic wind stress shear to force upwelling of bottom waters to the surface close to shore rises to the surface and results in a narrow band of cold sea surface temperature along the Vietnam coast (Fig. 2b, right). Off the northwestern coast of Luzon Island anticyclonic wind stress shear (Fig. 3a), interacting with the shelf break

\section{3, 21573-21608, 2013}

Primary productivity and its variability in the equatorial SCS

S. H. Ooi et al.

Title Page

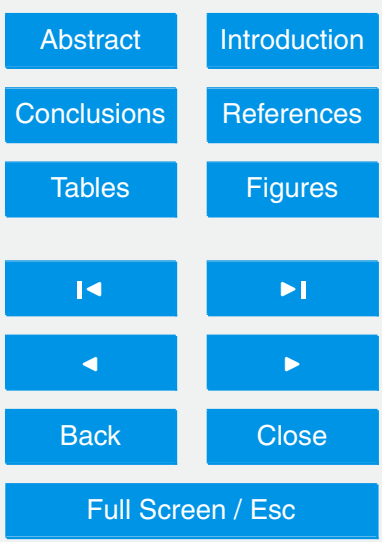

Printer-friendly Version

Interactive Discussion 
to the northwest, causes uplift of colder bottom waters, thus inducing upwelling. The relatively strong sea surface wind stresses in conjunction with the directional alignment of the shelf break lead to the existence of only these two seasonal upwelling regions in the whole of the SCS in the early winter monsoon season.

\section{$5 \quad 3.4$ Sea surface wave}

Consistent with the prevailing winds (Fig. 2, left), the surface waves propagate persistently from northeast to southwest over almost the whole of the SCS during November to March (Fig. 4, left). At the peak of the monsoon, late December and January, the northeast-southwest oriented $2 \mathrm{~m}$ significant wave height/swell band propagates as far south as $6^{\circ} \mathrm{N}$ with periods between 6 and $8 \mathrm{~s}$. High waves approach the shallow continental shelf and interact with the seafloor. Such interaction results in decreased wave speed, increased wave height, and eventually wave breaking. The shallow water at this time in the Sunda Shelf is thus very turbulent and allows for efficient vertical mixing.

\subsection{Sea surface current}

15 The sea surface currents in the SCS are linked to wind-driven currents caused by the trade winds in the Pacific (Wrytki, 1961). Beginning from October till November, the North Equatorial Drift current causes water to flow from the western North Pacific into the SCS through the Bashi Strait between Taiwan and Luzon Island (Fig. 4a, right). Sea surface heights along the South China coast rise and are considerably higher than in the vicinity of Luzon Island. This leads to the establishment of a gradient current which combines with the monsoon driven frictional drift current to form a southward flowing current. This occurs along and around the Vietnam coast and at the same time cooler waters are advected into the equatorial region (see Sect. 3.2 on SSTs for more details). The current subsequently flows into the Gulf of Thailand and along the coastal waters off the east coast of Peninsular Malaysia. Close to the equator one branch of the current is channeled into the Straits of Malacca and one other is swinging back north as

\section{ACPD}

13, 21573-21608, 2013

Primary productivity and its variability in the equatorial SCS

S. H. Ooi et al.

Title Page

Abstract

Introduction

Conclusions

References

Tables

Figures

14

$\rightarrow$

4

Back

Close

Full Screen / Esc

Printer-friendly Version

Interactive Discussion 
a cyclonic eddy (centered around $7^{\circ} \mathrm{N}, 109^{\circ} \mathrm{E}$ ) in the southern part of the South China Sea. November is the month of maximum tropical depression/storm frequency in the South China Sea between $8-18^{\circ} \mathrm{N}$ and $107-115^{\circ} \mathrm{E}$. The associated wind flow has thus contributed to the development of the cyclonic counter current. A minor branch of the 5 North Equatorial Drift enters the South China Sea through the inland seas such as the Celebes Sea and Sulu Sea. The warmer current not only flows along the coastal waters of Sabah and Sarawak but also branches and swings back to merge with the cyclonic eddy.

In December and January the northeast monsoon has fully developed. The currents 10 grow in strength and width off the shore of Vietnam (Fig. 4b, right). The cyclonic eddy still persists due to the presence of Borneo vortices but is shifted slightly to the east. In comparison to November more water flows into the center of the SCS through the inland seas of the central Philippines and is then mixed with the main current. The warmer current flowing along the coastal waters of Sabah and Sarawak also increases 15 its width slightly.

By February and March (Fig. 4c, right), though the main current pattern is almost the same as in January, the cyclonic eddy has weakened. However, the warmer current flowing along the coastal waters of Sabah and Sarawak increases further in width. This is consistent with the retreat of SST cold tongue northwards during the abating phase

\subsection{Chlorophyll a concentration}

Phytoplanktons are primary producers of carbon biomass through the process of photosynthesis (PRESPO and IOCCG, 2011). The chlorophyll pigment, and thus the concentration of chlorophyll $a$ is an indicator of phytoplankton amounts.

25 Figure 5 shows the climatological chlorophyll a concentrations for the winter monsoon season as observed by MODIS. In general the open equatorial South China Sea has low and nearly homogenous chlorophyll a concentrations not exceeding $0.2 \mathrm{mg} \mathrm{m}^{-3}$. The value becomes very high in coastal waters. Chlorophyll a concen21583
ACPD

13, 21573-21608, 2013

Primary productivity and its variability in the equatorial SCS

S. H. Ooi et al.

Title Page
Abstract

Conclusions

Tables

14

4

Back 
trations between 0.7 to $\sim 10 \mathrm{mg} \mathrm{m}^{-3}$ are observed along the coastal shores of East Malaysia in a belt of about 1-1 $1 / 2^{\circ}$ width. Along the coast of Peninsular Malaysia high chlorophyll a values are confined to a narrower belt of less than $1 / 2^{\circ}$ width. A slight width expansion occurs in February along the coast of Sabah and Sarawak.

Prevailing converging surface winds along the shore of East Malaysia and near perpendicular to the east coast of Peninsular Malaysia (Fig. 2, left) are leading to the spatial features of chlorophyll a concentrations observed. The development of the pattern is aided by the along shore sea surface currents (Fig. 4, left). Owing to the absence of seasonal upwelling, high chlorophyll a concentrations are mainly caused by enhancements of matter (coastal pollution) and nutrient (agricultural fertilizers and animal wastes) sources from inland sediment discharges and enhanced river runoff from high precipitation in areas with impervious watersheds. Malaysia has a wide extent of coastal mangrove areas. Mangroves are known to be sediment traps and sinks for nutrients. In the proximity of the coast, the increased nutrient supply from the bottom of the shallow water in the Sunda Shelf is caused by efficient vertical mixing due to turbulent high waves generated by strong winds when waves move toward the shallow continental shelf from the deep sea basin and subsequent transport towards the coast as waves break (as discussed in Sect. 3.4).

There is a significant widening of enhanced chlorophyll a concentrations (up to $20 \quad 0.5 \mathrm{mg} \mathrm{m}^{-3}$ ) during December (Fig. $5 \mathrm{~b}$ ) from the southern tip of Vietnam towards the Gulf of Thailand and east coast of Peninsular Malaysia by the strong westward and southwestward flowing currents towards the Gulf and the south-southwestward currents towards Peninsular Malaysia (not shown). In January "dilution" lowers the chlorophyll a concentrations to $0.3-0.4 \mathrm{mg} \mathrm{m}^{-3}$ along the coastal stretch of Sabah and 25 Sarawak (Fig. 5c). This is due to the convergence of eastward currents from the west and westward currents from the east into the cyclonic eddy (Fig. 4b, right). In February and March, there is a widening of the high chlorophyll a concentration belt along the coastal area of Sabah and Sarawak (Fig. $5 d$ and e). During this period, the monsoon generally weakens, causing the clockwise change and decreasing strength of surface

ACPD

13, 21573-21608, 2013

Primary productivity and its variability in the equatorial SCS

S. H. Ooi et al.

Title Page

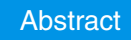

Introduction

Conclusions

References

Tables

Figures

14

$\rightarrow 1$

4

Back

Close
Printer-friendly Version

Interactive Discussion

Full Screen / Esc

(1) 
winds near the coast (Fig. 2c, left). This favours not only the occurrence of coastal and near-coastal convective thunderstorms (not shown) but also strengthens the influence of tides interacting with coastal topography. This leads to the occurrence of more turbulent mixing that result in more efficient transport of nutrients from bottom waters to 5 the surface. In addition, the alongshore current induced by refracted waves coming at an oblique angle towards the coast can deposit those nutrient-loaded sediments from inland sources along the coast.

As shown in Sect. 3.3, there are two seasonal upwelling regions located northwest off Luzon Island and southeast off the Vietnam coast in the South China Sea during 10 November and January. As noted by Lin et al. (2003) and Scowcroft et al. (2011), vertical mixing occurs when a typhoon/hurricane passes over the surface of the ocean. The typhoon/hurricane's winds create turbulence in the ocean, which mixes the surface water with the water below. In November (Fig. 5a), though the cyclonic wind stress shear is relatively weak off the Vietnam coast, the resultant vertical mixing from the presence

\section{Winter monsoon variability}

In the equatorial SCS, monsoon intensity varies within a season (intraseasonal) and from year-to-year (interannual). Changes in mean sea level pressure, surface wind, sea surface current, sea surface temperature and precipitation are intrinsically linked. In this section, we investigate changes in coupled atmosphere-ocean processes and how they impact chlorophyll a concentrations.

It should be noted how intrinsically linked cold surges, Borneo vortices and ENSO events are. Chang et al. (2005) showed that cold surges and associated Borneo vor-

\section{ACPD}

13, 21573-21608, 2013

Primary productivity and its variability in the equatorial SCS

S. H. Ooi et al.

Title Page
Abstract

Conclusions

Tables

14

4

Back
Introduction

References

Figures

$\rightarrow$

Close
Full Screen / Esc

Printer-friendly Version

Interactive Discussion 
tices have a periodicity of 2-15 days. Our preliminary analysis using the recent $30 \mathrm{yr}$ base period of ERA-interim wind data (1981-2010) reveals that there is an average of 4 to 5 "cold surges" in each winter monsoon season over the SCS and 1 or 2 of them can be classified as strong cases (not shown). In general, strong cold surges 5 are associated with La Niña while weak surges are linked with El Niño. However, in El Niño years, the total number of Borneo vortex occurrences can be higher due to more easterly "surges".

In Sect. 4.1, the seasonal progression is examined using differences between consecutive months. It is well established that a dominant factor of interannual variability in 10 the SCS region is the El-Niño Southern Oscillation (ENSO) phenomenon (Ooi, 1999). The ENSO impact of chlorophyll a will be investigated in Sect. 4.2.

\subsection{Intraseasonal variability}

Figure 6 shows differences of some key meteorological and oceanic parameters between consecutive months. Progressing from November to December, mslp increases by about $2.5 \mathrm{hPa}$ from China southeastwards towards the northwestern Pacific while the axis of slightly decreased mslp is visible parallel to the coastline of East Malaysia (Fig. 6a). The surface northeasterlies reach as far south as the equator (Fig. 6b). Along the coastal band of East Malaysia, northeastward and southwestward flowing currents converge near the mid-point of the band (Fig. 6c). A strong decrease of SSTs (of around $2^{\circ} \mathrm{C}$ ) is observed nearly everywhere in the SCS. It is caused by subsequent cold surge spells. Smaller decreases are seen in coastal waters (east coast of Peninsular Malaysia and East Malaysia) (Fig. 6d). A small decrease in SSTs at the East Malaysian side is due to convergence of two warm currents from the Pacific (through the Sulu Sea) and south of the equator as described above. In response to the interaction of cold surge events and the climatological near-equatorial trough during November and December, a significant increase of rainfall $(\sim 100-150 \mathrm{~mm})$ occurs over almost the whole of the equatorial South China Sea (including Malaysia) except the northwestern part of the open sea (Fig. 6e). While the whole sea area of this region generally shows a small

\section{ACPD}

13, 21573-21608, 2013

Primary productivity and its variability in the equatorial SCS

S. H. Ooi et al.

Title Page

Abstract

Introduction

Conclusions

References

Tables

Figures

14

$\rightarrow 1$

4

Back

Close
Printer-friendly Version

Interactive Discussion

Full Screen / Esc Discussion 
increase in chlorophyll a concentrations $\left(\sim 0.3 \mathrm{mg} \mathrm{m}^{-3}\right)$, the narrow coastal band $\left(\sim 1^{\circ}\right.$ latitude) along East Malaysia (except western Sabah) shows a significant increase of around $1-2 \mathrm{mg} \mathrm{m}^{-3}$ (Fig. 7a). This is due to the combined effect of converging surface northeasterlies, turbulent vertical mixing by wind-generated high waves, converging

5 warm surface currents and increased high precipitation run-off particularly from inland areas.

Chlorophyll a concentrations begin to increase along the coast of East Malaysia during November. Concentrations peak in January (Fig. 7b), and are nearly constant throughout February (Fig. 7c). A general decrease is observed from February to March

10 (Fig. 7d). One factor for the increase of chlorophyll $a$ in the early phase of the northeast monsoon (until January) is the convergence of surface northeasterlies. This meteorological condition aids the occurrence of breaking high waves and consequently allows efficient vertical ocean mixing to happen. The bloom is also supported by favorable sea surface currents and intense river runoff and discharges from high precipitation. The concentration fluctuations in February are influenced by a northerly flow from the open sea and the variability of sea surface current eddies. Finally, with lesser influence from the variable sea surface current eddies along the coast, the southerly surface wind appears to be the dominant factor in diluting the coastal concentration towards the open sea in March.

\subsection{Interannual variability}

In this section we characterize the ENSO related interannual variability in the SCS. We calculate anomalies by subtracting ENSO warm/cold composites from the longterm monthly averages for the period 2000-2009. The $10 \mathrm{yr}$ base period is chosen because it provides us with a "neutral" mean by excluding the strong 1997-1998 El Niño and 1999-2000 La Niña events. Years in this period can be classified based on the Southern Oscillation Index (SOI) (refer http://www.cpc.ncep.noaa.gov/products/ analysis_monitoring/ensocycle/soi.shtml). The years 2004 and 2006 were weak El
ACPD

13, 21573-21608, 2013

Primary productivity and its variability in the equatorial SCS

S. H. Ooi et al.

Title Page

Abstract

Introduction

Conclusions

References

Tables

Figures

14

$\rightarrow 1$

4

Back

Close

Printer-friendly Version

Interactive Discussion 
Niño years and 2002 was a moderate one. For La Niña years, 2000 was weak in intensity and in 2007 a moderate event was observed.

The winter monsoon intensifies during December and mslp changes between positive and negative phases of ENSO are significant. We thus select this month to discuss 5 the anomalies of some important parameters describing the state of the SCS. We start our discussion with El Niño (warm ENSO or negative SOI) followed by La Niña (cold ENSO or positive SOI). We note that that the period we study is short (restricted by the availability of satellite data), and that the results here are indicative only.

Figure $8 \mathrm{a}$ shows that the axis tilt of the positive mslp anomaly in the SCS during 10 El Niño years changes to southeast in December from northeast in November. Such change is consistent with the anomalous surface easterlies and northeasterlies observed over the equatorial SCS, in particular along the coastal bands of East Malaysia (Fig. 8b). Consequently the sea surface current adjusts as well (Fig. 8c). The anomalous surface currents are flowing northeastwards from the southwestern sector and 15 southwestwards from the northeastern sector. Both converge around the mid-point of the coastal areas in December and February while the flows are generally southwestwards in other months. At the same time ocean cyclonic eddy activity is centered around $6^{\circ} \mathrm{N} 109^{\circ} \mathrm{E}$ and persists from November to February. Further evidence for a systematic change in regional weather comes from precipitation changes (Fig. 8d) in which negative anomalies are observed in western Sabah and its coast.

In Fig. 9 we discuss the changes of chlorophyll a concentrations for the winter monsoon season during EI Niño years. The concentrations show a decrease from November to December (Fig. 9a and b) when El Niño maximises. The cause is mainly the diverging anomalous surface easterlies/northeasterlies along the whole coastal area (Roeloffzen et al., 1986). In January, the whole coastal area of East Malaysia shows decreased concentration (Fig. 9c) as a result of a precipitation deficit and in combination with diverging surface wind anomalies (Ooi and Azizan, 2013). In February and March the coastal band of Sarawak shows decreased concentrations while at western Sabah's coast increases (Figs. 9d and e) can be observed.

\section{ACPD}

13, 21573-21608, 2013

Primary productivity and its variability in the equatorial SCS

S. H. Ooi et al.

Title Page

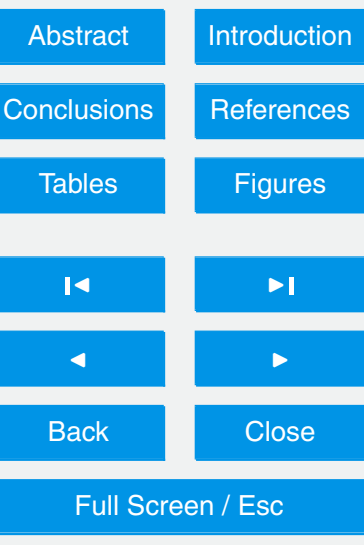

Printer-friendly Version

Interactive Discussion 
During La Niña years, the axis tilt of the negative mslp anomaly lies aligns southwest over southern China in December (Fig. 10a). This causes anomalous southwesterlies in the SCS (Fig. 10b). More intense oceanic cyclonic eddy activity is observed around $6^{\circ} \mathrm{N} 109^{\circ} \mathrm{E}$ and persists throughout the monsoon season. However, along the coastal 5 band of East Malaysia, anomalous sea surface currents flow towards the southwest in December (Fig. 10c) and towards the northeast in other months. In December increased precipitation is observed in western Sabah and its coastal regions (Fig. 10d).

In Fig. 11 chlorophyll a concentrations during La Niña years are shown. An increase can be seen in December (Fig. 11b), which can be attributed to the converging anoma10 lous southwesterlies along the whole coastal stretch of East Malaysia. However, in January concentrations along coastal areas of western Sabah show decreases while along coastal Sarawak a general increase is observed (Fig. 11c). In February and March increased and decreased concentrations appear along the coastal band of Sarawak and western Sabah, not forming a coherent pattern (Fig. 11d and e).

\section{$15 \quad 5$ A case study}

After discussing the climatological means, the seasonal progression, and interannual variability of flow patterns and chlorophyll a concentrations, we continue with discussing a case study of enhanced offshore phytoplankton growth due to a cold-surge induced Borneo Vortex event during January 2010.

20 Based on the synergy of three recent satellite data sets (SeaWiFS, TRMM and QuikScat), Lin et al. (2003) tracked the moderate cyclone Kai-Tak from 5 to 8 July 2000 in the SCS region north of $18^{\circ} \mathrm{N}$. They showed a 30 -fold increase (averaged over the observational period) in surface chlorophyll a concentrations due to strong nutrient pumping by vertical mixing and upwelling. In the equatorial SCS the effective Coriolis force is weak and upwelling is absent in the shallow waters of the continental shelf. The area is mostly cloudy when monsoon disturbances/Borneo vortices develop. The

\section{ACPD}

13, 21573-21608, 2013

Primary productivity and its variability in the equatorial SCS

S. H. Ooi et al.

Title Page

\section{Abstract}

Conclusions

Tables

14

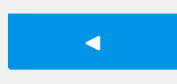

Back
Introduction

References

Figures

$\rightarrow 1$

Close
Full Screen / Esc

Printer-friendly Version

Interactive Discussion 
disturbances are commonly induced by cold surges during the early phase (November to mid-January) of the northeast monsoon.

Ooi et al. (2011) describe the detailed meteorology of a Borneo vortex event in January 2010. This Borneo vortex, initiated by a cold surge, occurred from 13 to 19 January

5 2010. It developed into a tropical depression on 18 January 2010 before dissipating near the southeastern coast of Vietnam. We selected the wind surge period (16-20 January 2010) to assess the impact of this event on the chlorophyll a concentrations.

Figure $12 a$ shows the anomaly of $\operatorname{mslp~}(\mathrm{hPa})$ for the period 16-20 January 2010 (relative to the climatology in Fig. 2b). The minimum in mslp around $7^{\circ} \mathrm{N}$ and $112^{\circ} \mathrm{E}$ 10 indicates the center position of the Borneo vortex in its developed phase.

Figure $12 \mathrm{~b}$ shows the averaged surface wave vector with period (s) shaded and height/swell $(\mathrm{m})$ contoured. A wave height of $2.5 \mathrm{~m}$ is observed parallel to the edge of the continental shelf along $108^{\circ} \mathrm{E}$. This height increase is caused by positive interference of waves radiating away from the developing Borneo vortex.

Figure $12 \mathrm{c}$ and d show the sea surface wind stress $\left(\mathrm{Nm}^{-1}\right)$ and sea surface currents $\left(\mathrm{m} \mathrm{s}^{-1}\right)$ respectively averaged over the period 16-20 January 2010. It is interesting to note that the wind stress vectors and the surface current vectors are almost parallel (see our discussion in Sect. 2 with respect to shallow waters).

Figure $12 \mathrm{e}$ shows the mean and Fig. $12 \mathrm{f}$ the anomaly of chlorophyll a concentrations $20 \quad\left(\mathrm{mg} \mathrm{m}^{-3}\right)$ during the period 16-20 January 2010 . Figure $12 \mathrm{e}$ shows a high chlorophyll $a$ concentration of $0.5 \mathrm{mg} \mathrm{m}^{-3}$ and a moderate increase of about $0.3 \mathrm{mg} \mathrm{m}^{-3}$ (Fig. 12f) were located between $2-9^{\circ} \mathrm{N}$ and $107-111^{\circ} \mathrm{E}$ (bearing in mind that the cloudy conditions only permit partial coverage of satellite data). This can be attributed to the fact that turbulence increases due to the high waves (Fig. 12b). On entering the shallow waters waves break and enhanced vertical mixing occurs, bringing not only colder waters (not shown) but also nutrients from the bottom up to the top.

ACPD

13, 21573-21608, 2013

Primary productivity and its variability in the equatorial SCS

S. H. Ooi et al.

Title Page

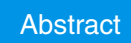

Introduction

Conclusions

References

Tables

Figures

14

- I

4

Back

Full Screen / Esc

Printer-friendly Version

Interactive Discussion 


\section{Discussions and conclusions}

Our analysis of key atmospheric and oceanic parameters over the period 2000-2009 seems representative of longer-term mean conditions in the region as discussed by Lim and Azizan (2004). We would therefore assume that the observed chlorophyll a 5 concentrations are representative as well.

High concentrations of chlorophyll $a$ along the coastlines of East Malaysia and the east coast of Peninsular Malaysia originate from inland runoff of high precipitation and sediment discharge. Converging prevailing surface winds and sea surface currents are responsible in keeping the chlorophyll $a$ in coastal areas. The increased supply of nutri-

ents in the near and off coast areas is mainly brought about by efficient vertical mixing due to turbulent high waves generated by strong winds and subsequent transport towards the coast by the breaking waves when the waves move towards the shallow continental shelf from the deep sea basin in the early phase of the northeast monsoon. Enhancing and diluting of chlorophyll a concentration towards and away from the coast in certain months are also strongly modulated by the current flow. In the later phase of the northeast monsoon, widening of the high chlorophyll a concentration off coast of East Malaysia is mainly due to the increasing influence of tides on interaction with coastal topography. In the presence of a Borneo vortex, a modest increase of high chlorophyll a concentrations in the open sea is likely due to increased vertical mixing.

Understanding better the intraseasonal and interannual variabilities of chlorophyll a concentration is highly essential to determine phytoplankton blooms in the equatorial South China Sea, particularly along the coastal waters of East Malaysia. Based on monthly mean data we discuss the seasonal progression. The concentrations begin to increase along the coast of East Malaysia from November onwards. They peak in 25 January, show fluctuations during February, and decrease during March. Interannual variability of chlorophyll a concentrations is dominated by the ENSO phenomenon. A decrease can be observed during EI Niño and an increase during La Niña (from November to December). No clear ENSO large-scale impact has been observed from
ACPD

13, 21573-21608, 2013

Primary productivity and its variability in the equatorial SCS

S. H. Ooi et al.

Title Page

Abstract

Introduction

Conclusions

References

Tables

Figures

14

- I

4

Back

Close 
January to March. However, one unique feature along the shore of western Sabah is identified: a bloom during El Niño and a significant decrease of concentrations during La Niña in February and March. For blooms to occur, there must be a high amount of nutrients that are needed for photosynthesis. The location of phytoplankton blooms 5 during the northeast monsoon can be summarized as follows:

- southwestern coast of west Sabah in December during La Niña;

- northeastern coast of west Sabah from January to March during El Niño; and

- along the coastal waters of Sarawak in January during La Niña.

The schematic shown in Fig. 13 summarises the impacts of ENSO on the variability of chlorophyll a concentrations.

Locating phytoplankton blooms is very significant economically and socially. For examples, the blooms enable one to identify useful microalgae biomass potential as feedstock for biofuels and co-products that may have applications as food and health supplements. Socially, toxic algae blooms (or red tides) are considered harmful or lethal 15 to human beings and these are reported occasionally in Sabah and Sarawak (East Malaysia). It is known that marine photosynthesis undertaken by phytoplankton represents approximately half of the total carbon fixation in the global biosphere, making it a critical element of the Earth's carbon budget and biogeochemical cycles (PRESPO and IOCCG, 2011). The evolution of such biological pump thus plays a key role in understanding climate change scenarios, inclusive of the trace gas emission source and strength. More detailed case studies are needed to explore further those known and unknown/unclear processes so as to harness the potentials of phytoplanktons in response to their significant social and economic impacts.

Acknowledgements. ERA-Interim reanalysis data were provided by the ECMWF and the data 25 analysis of this study was carried out using the Grid Analysis and Display System (GrADS) software from OpenGrADS. Remote sensing data on chlorophyll a concentration, sea surface temperature, TRMM daily precipitation were downloaded from the Giovanni system while the

\section{ACPD}

13, 21573-21608, 2013

Primary productivity and its variability in the equatorial SCS

S. H. Ooi et al.

Title Page

Abstract

Introduction

Conclusions

Tables

References

Figures

14

$\rightarrow 1$

4

Back

Close

Full Screen / Esc

Printer-friendly Version

Interactive Discussion
$>$

ractive Discussion

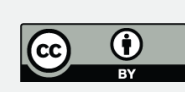


monthly surface current data was obtained from the OSCAR Project Office. This research study is collectively funded by the Malaysian Government eScienceFund Grant 04-01-03-SF0410 and the European Union's Seventh Framework Programme FP7/2007-2013 under grant agreement no. 226224 - SHIVA. It is also strongly supported by the Vice Chancellors of the University

\section{References}

Braesicke, P., See Hai, O., and Abu Samah, A. : Properties of strong off-shore Borneo vortices: a composite analysis of flow pattern and composition as captured by ERA-Interim, Atmos. Sci. Lett., 13, 128-132, doi:10.1002/asl.372, 2012.

Chang, C.-P., Harr, P. A., and Chen, H.-J.: Synoptic disturbances over the equatorial South China Sea and western maritime continent during boreal winter, Mon. Weather Rev., 133, 489-503, doi:10.1175/MWR-2868.1, 2005.

DanLing Tang, Hiroshi Kawamura, Tran Van Dien, and MingAn Lee: Offshore phytoplankton biomass increase and its oceanographic causes in the South China Sea, Mar. Ecol.-Prog.

15 Ser., 268, 31-41, 2004.

Dee, D. P., Uppala, S. M., Simmons, A. J., Berrisford, P., Poli, P., Kobayashi, S., Sndrae, U., Balmaseda, M. A., Balsamo, G., Bauer, P., Bechtold, P., Beljaars, A. C. M., van de Berg, L., Bidlot, J., Bormann, N., Delsol, C., Dragani, R., Fuentes, M., Geer, A. J., Haimberger, L., Healy, S. B., Hersbach, H., Holm, E. V., Isaksen, L., Kalberg, P., Kohler, M., Matricardi, M., McNally, A. P., Monge-Sanz, B. M., Morcrette, J.-J., Park, B.-K., Peubey, C., de Rosnay, P., Tavolato, C., Thepaut, J.-N., and Vitart, F.: The ERA-Interim reanalysis: configuration and performance of the data assimilation system, Q. J. Roy. Meteor. Soc., 137, 553-597, 2011.

Gray, W. M. and Jacobson Jr., R.: Diurnal variation of deep cumulus convection, Mon. Weather Rev., 105, 1171-1188, 1977.

25 IPRC: South China Sea Takes Center Stage, IPRC Climate, Vol. 4, No. 2, 2005.

Lim Joo Tick and Azizan Abu Samah: Weather and Climate of Malaysia, University of Malaya Press, 2004.

Lin, I., Liu, W. T., Wu, C. C., Wong, G. T. F., Hu, C. M., Chen, Z. Q., Liang, W. D., Yang, Y., and Liu, K. K.: New evidence for enhanced ocean primary production triggered by tropical

\section{ACPD}

13, 21573-21608, 2013

Primary productivity and its variability in the equatorial SCS

S. H. Ooi et al.

\section{Title Page}


Liu, K.-K., Chao, S.-Y., Shaw, P.-T., Gong, G.-C., Chen, C.-C., and Tang, T. Y.: Monsoon-forced chlorophyll distribution and primary production in the South China Sea: observations and a numerical study, Deep-Sea Res. Pt. I, 49, 1387-1412, 2002.

Ooi See Hai: Impacts of ENSO on Monsoons over Malaysia. ESCAP/WMO Typhoon Committee Annual Review 1998, World Meteorological Organization, Geneva, 153-173, 1999.

Ooi See Hai and Azizan Abu Samah: Impacts of air-sea interaction over the equatorial South China Sea during the northeast monsoon on marine activities and resources in the Malaysian coastal and continental shelf waters, eScienceFund Project Report \#2: Intraseasonal and Interannual Variabilities, 62 pp., 2013.

10 Ooi, S. H., Samah, A. A., and Braesicke, P.: A case study of the Borneo Vortex genesis and its interactions with the global circulation, J. Geophys. Res., 116, D21116, doi:10.1029/2011JD015991, 2011.

PRESPO and IOCCG: Handbook of Satellite Remote Sensing Image Interpretation: Applications for Marine Living Resources Conservation and Management, edited by: Morales, J., Stuart, V., Platt, T., and Sathyendranath, S. and published by the EU PRESPO Project and IOCCG (International Ocean-Colour Coordinating Group), 2011.

Pyle, J. A., Warwick, N. J., Harris, N. R. P., Mohd Radzi Abas, Archibald, A. T., Ashfold, M. J., Ashworth, K., Barkley, M. P., Carver, G. D., Chance, K., Dorsey, J. R., Fowler, D., Gonzi, S., Gostlow, B., Hewitt, C. N., Kurosu, T. P., Lee, J. D., Langford, S. B., Mills, G., Moller, S., MacKenzie, A. R., Manning, A. J., Misztal, P., Mohd Shahrul Mohd Nadzir, Nemitz, E., Newton, H. M., O'Brien, L. M., Ong, S., Oram, D., Palmer, P. I., Leong Kok Peng, Siew Moi Phang, Pike, R., Pugh, T. A. M., Noorsaadah Abdul Rahman, Robinson, A. D., Sentian, J., Azizan Abu Samah, Skiba, U., Huan Eng Ung, Sei Eng Yong, and Young, P. J.: The impact of local surface changes in Borneo on atmospheric composition at wider spatial scales: coastal processes, land-use change and air quality, Philos. T. Roy. Soc. B, 366, 3210-3224, 2011.

Roeloffzen, J. C., Van Den Berg, W. D., and Oerlemans, J.: Frictional convergence at coastlines, Tellus A, 38, 397-411, doi:10.1111/j.1600-0870.1986.tb00473.x, 1986.

Scowcroft, G., Ginis, I., Knowlton, C., Yablonsky, R., and Morin, H.: Hurricanes: Science and Society, University of Rhode Island, 16 pp., 2011.

30 Stewart, R. H.: Introduction To Physical Oceanography, Web textbook of Department of Oceanography, Texas A \& M University, 2008.

Suhung Shen, Rui, H., Liu, Z., Zhu, T., Lu, L., Berrick, S., Leptoukh, G., Teng, W., Acker, J., Johnson, J., Ahmad, S. P., Savtchenko, A., Gerasimov, I., and Kempler, S.: Giovanni: A Sys-

\section{ACPD}

13, 21573-21608, 2013

Primary productivity and its variability in the equatorial SCS

S. H. Ooi et al.

Title Page

\section{Abstract}

Conclusions

Tables

14

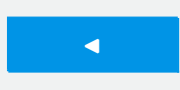

Back
Introduction

References

Figures

$\rightarrow 1$

Close
Full Screen / Esc

Printer-friendly Version

Interactive Discussion 
tem for Rapid Access, Visualization and Analysis of Earth Science Data Online, NASA Technical Reports Series, 2007.

Suhung Shen, Leptoukh, G. G., Acker, J. G., Zuojun Yu, and Kempler, S. J.: Seasonal Variations of Chlorophyll a Concentration in the Northern South China Sea, IEEE Geosci. Remote $5 \quad$ Sens., 5, 315-319, doi:10.1109/LGRS.2008.915932, 2008.

Wrytki, K.: NAGA Report, Volume 2, Scientific results of the South China Sea and Gulf of Thailand 1959-1961, University of California, Scripps Institution of Oceanography, Le Jolla, California, 195 pp., 1961.

Zhang, Y., Sperber, K. R., and Boyle, J. S.: Climatology and interannual variation of the East Asian Winter Monsoon: Results from the 1979-95 NCEP/NCAR reanalysis, Mon. Weather Rev., 125, 2605-2619, 1997.

\section{ACPD}

13, 21573-21608, 2013

Primary productivity and its variability in the equatorial SCS

S. H. Ooi et al.

\section{Title Page}

Abstract

Introduction

Conclusions

References

Tables

Figures

14

$\rightarrow 1$

4

Back

$>$

Close

Full Screen / Esc

Printer-friendly Version

Interactive Discussion 


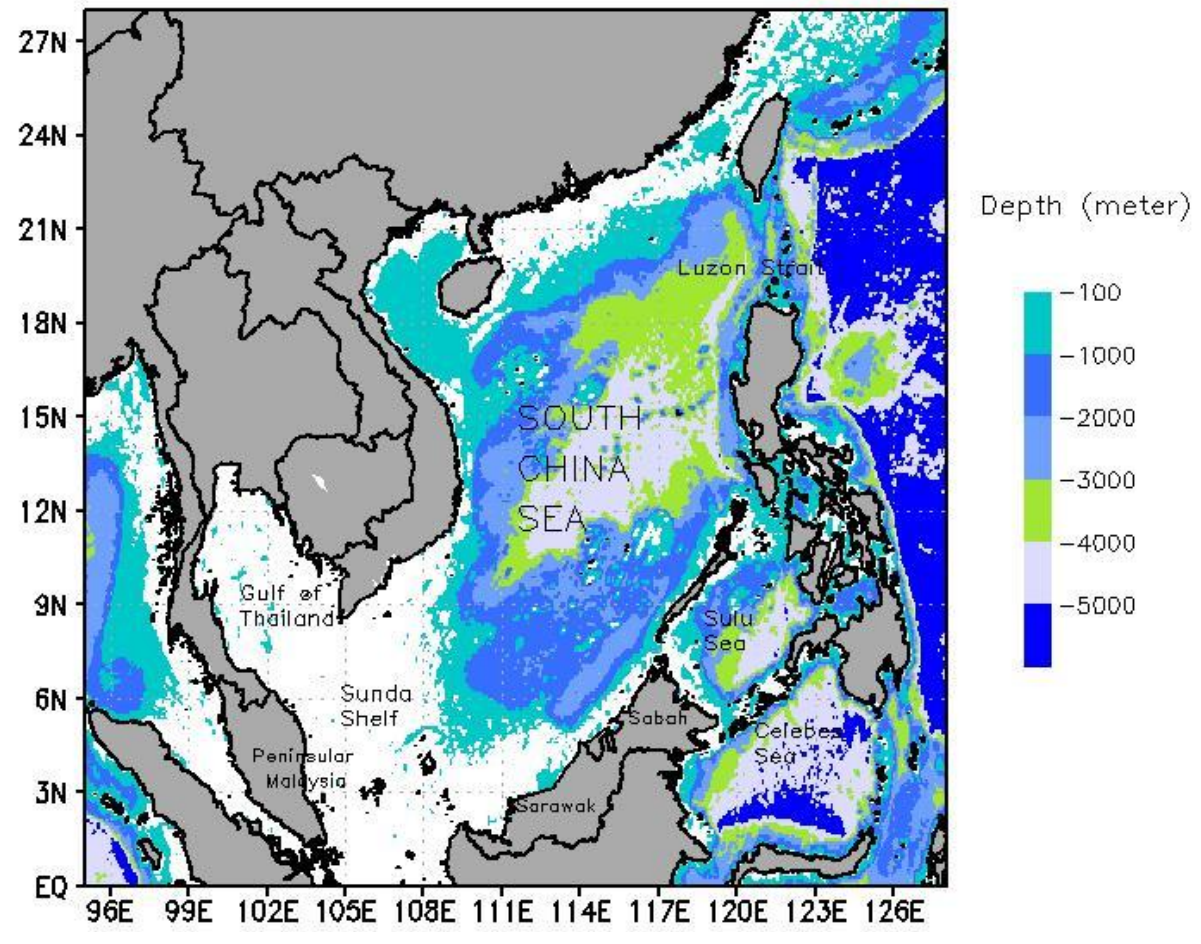

Fig. 1. The geography and bathymetry of the South China Sea (Data source: Smith and Sandwell).

\section{ACPD}

\section{3, 21573-21608, 2013}

Primary productivity and its variability in the equatorial SCS

S. H. Ooi et al.

\section{Title Page}

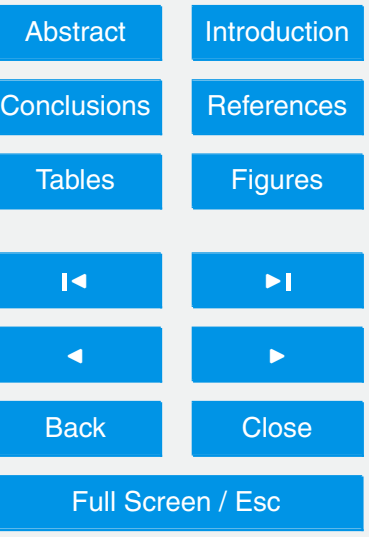

Printer-friendly Version

Interactive Discussion

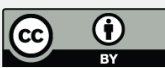



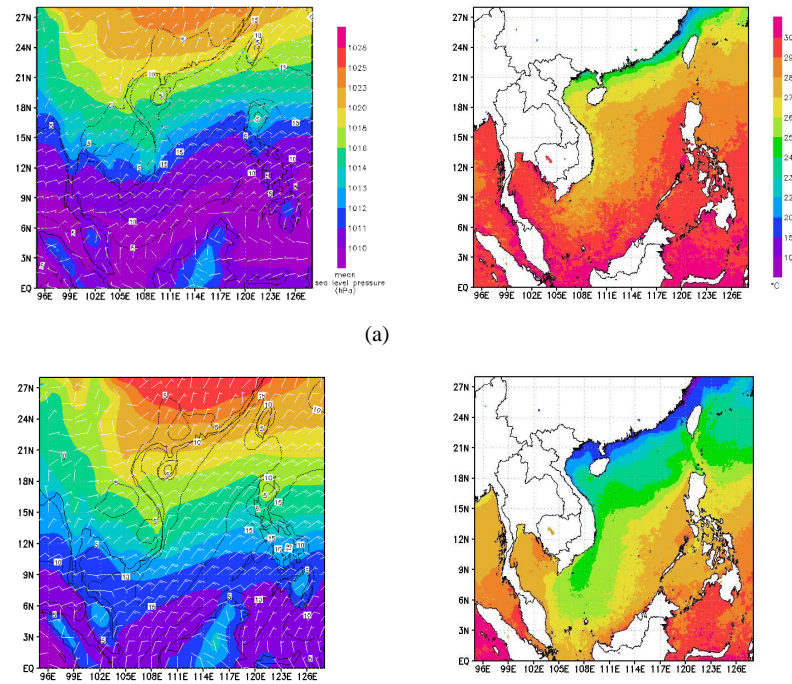

(b)
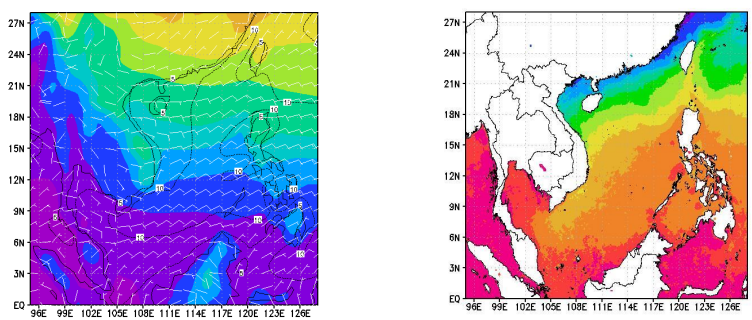

(c)

Fig. 2. Climatological mean sea level pressure (left, in $\mathrm{hPa}$ and shaded) superimposed with surface wind (in barbs with contoured magnitude at $5 \mathrm{knots}$ interval) and sea surface temperature (right, in ${ }^{\circ} \mathrm{C}$ and shaded) at 00:00 UTC for (a) November, (b) January and (c) March.

\section{ACPD}

13, 21573-21608, 2013

Primary productivity and its variability in the equatorial SCS

S. H. Ooi et al.

Title Page

Abstract

Introduction

Conclusions

References

Tables

Figures

14

$>1$

4

Back

Close 


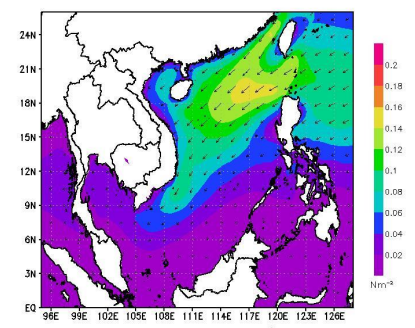

(a)

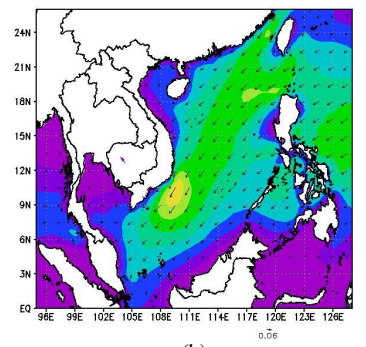

(b)

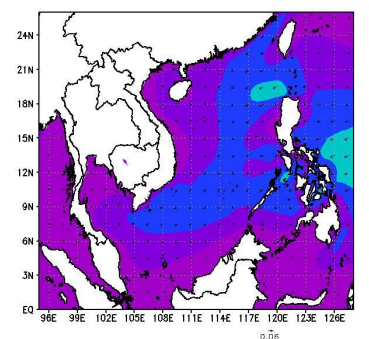

(c)

Fig. 3. Climatological sea surface wind stress (in $\mathrm{Nm}^{-2}$ or $\mathrm{Pa}$ and shaded) at 00:00 UTC for (a) November, (b) January and (c) March.

ACPD

13, 21573-21608, 2013

Primary productivity and its variability in the equatorial SCS

S. H. Ooi et al.

\section{Title Page}

Abstract

Introduction

Conclusions

References

Tables

Figures

$1<$

$>1$

4

Back

Close

Full Screen / Esc

Printer-friendly Version

Interactive Discussion 

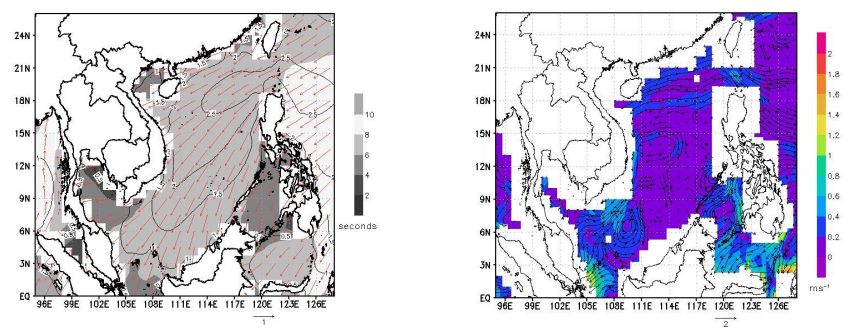

(a)
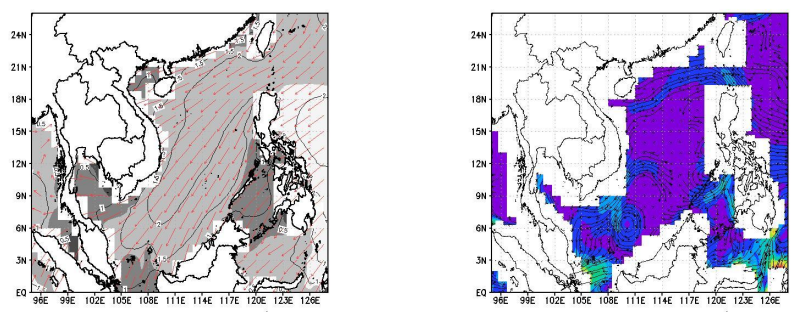

(b)

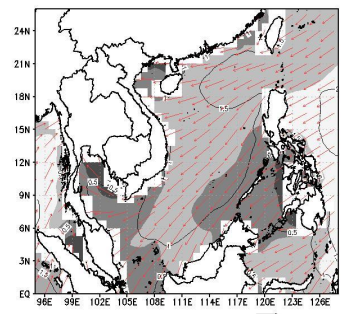

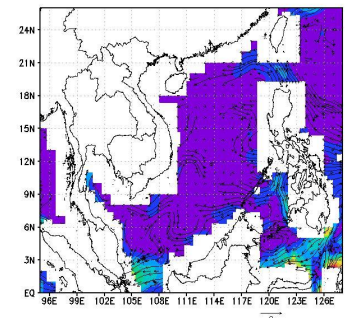

(c)

\section{ACPD}

13, 21573-21608, 2013

Primary productivity and its variability in the equatorial SCS

S. H. Ooi et al.

Title Page

Abstract

Introduction

Conclusions

References

Tables

Figures

14

$>1$

Back

$>$

Close

\section{Full Screen / Esc}

Printer-friendly Version

Interactive Discussion

Fig. 4. Climatological wave (vector with period (s) shaded and height/swell $(\mathrm{m})$ contoured) on the left and OSCAR sea surface current vector $\left(\mathrm{m} \mathrm{s}^{-1}\right.$, flow by streamlines while magnitude is shaded) on the right for (a) November, (b) January and (c) March. 


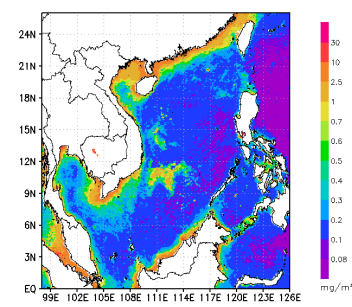

(a)

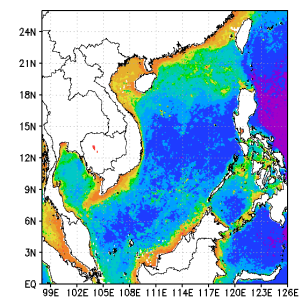

(c)

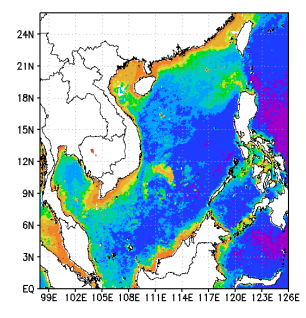

(b)

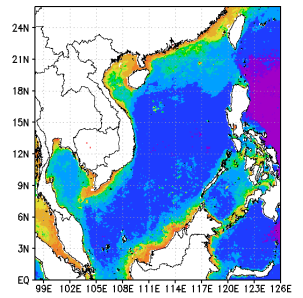

(d)

\section{ACPD}

13, 21573-21608, 2013

Primary productivity and its variability in the equatorial SCS

S. H. Ooi et al.

\section{Title Page}

\section{Abstract}

Introduction

Conclusions

References

Tables

Figures

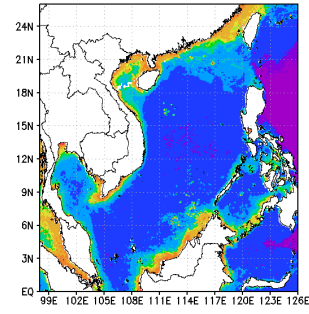

(e)

Fig. 5. Climatological chlorophyll a concentration $\left(\mathrm{mg} \mathrm{m}^{-3}\right)$ for (a) November, (b) December, (c) January, (d) February and (e) March.
14

4

Back

\section{Full Screen / Esc}

Printer-friendly Version

Interactive Discussion 


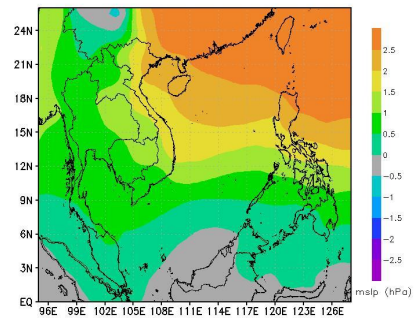

(a)

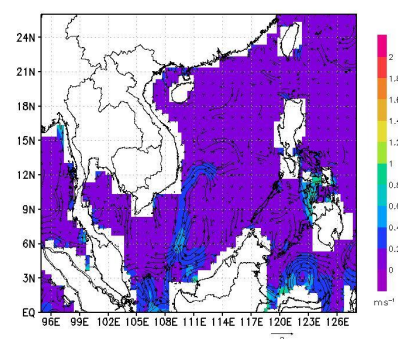

(c)

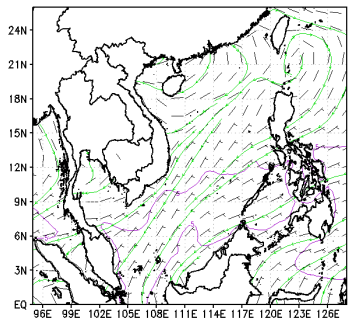

(b)

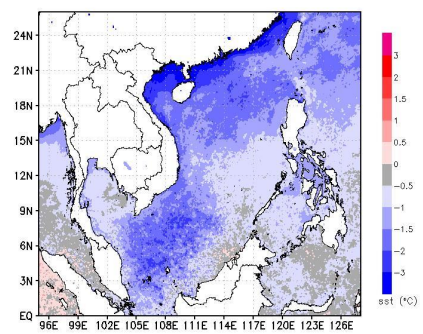

(d)

\section{ACPD}

13, 21573-21608, 2013

Primary productivity and its variability in the equatorial SCS

S. H. Ooi et al.

\section{Title Page}

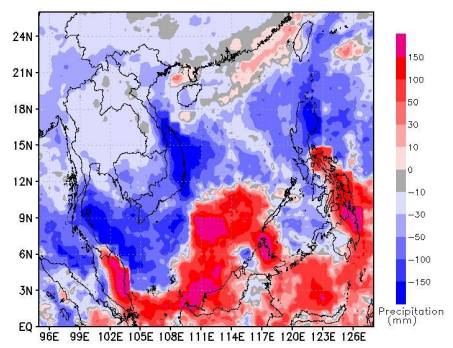

4

\section{Full Screen / Esc}

Printer-friendly Version

Interactive Discussion

Fig. 6. Difference (current month - preceding month) in average (a) mean sea level pressure, (b) sea surface wind, (c) sea surface current, (d) sea surface temperature and (e) precipitation between December and November. 


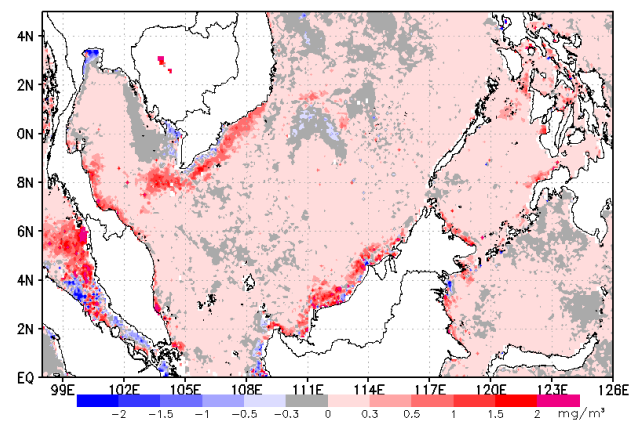

(a)

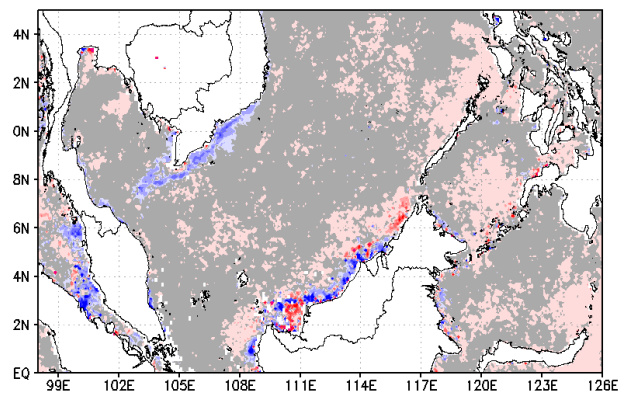

(c)
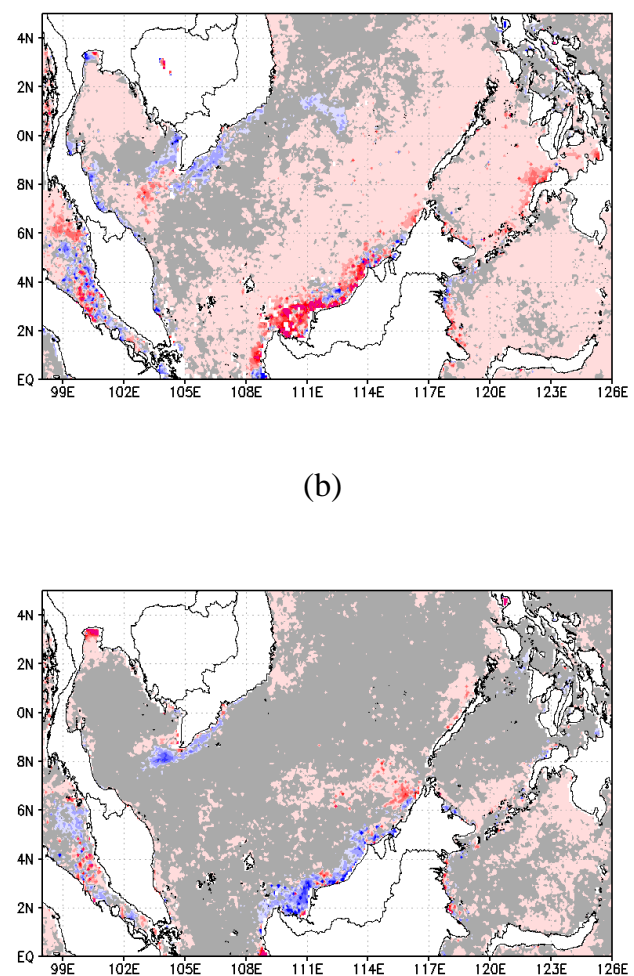

(b)

(d)

Fig. 7. Difference (current month - preceding month) in average chlorophyll a concentration (a) between December and November, (b) between January and December, (c) between February and January and (d) between March and February.

\section{ACPD}

13, 21573-21608, 2013

Primary productivity and its variability in the equatorial SCS

S. H. Ooi et al.

\section{Title Page}

Abstract

Introduction

Conclusions

References

Tables

Figures

14

$\rightarrow 1$

4

Back

Close

\section{Full Screen / Esc}

Printer-friendly Version

Interactive Discussion 


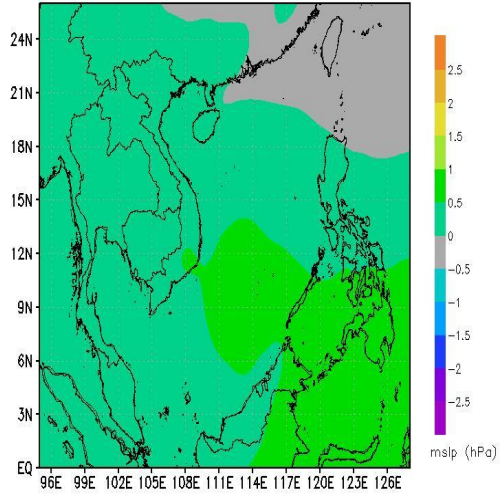

(a)

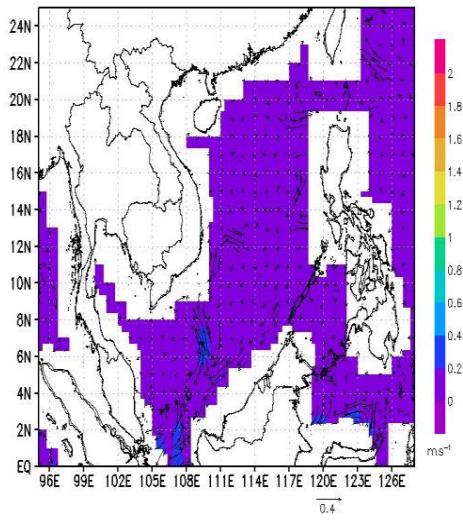

(c)

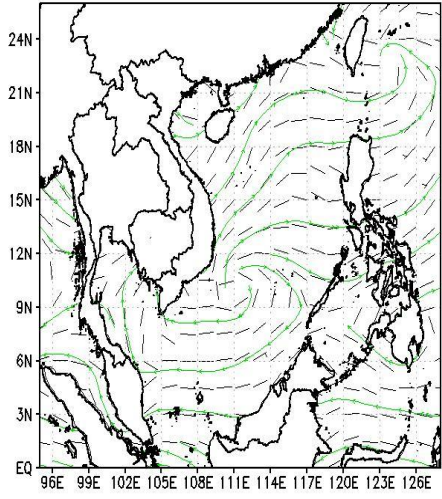

(b)

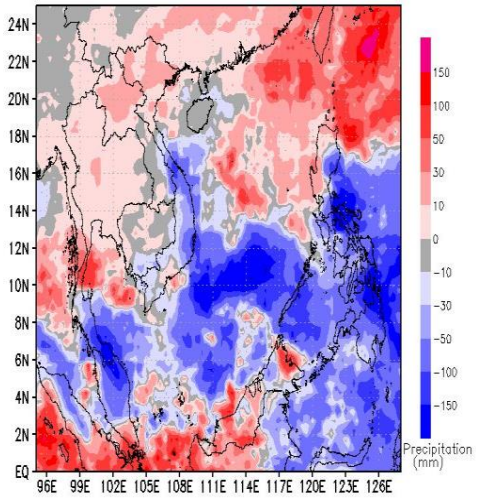

(d)
ACPD

13, 21573-21608, 2013

Primary productivity and its variability in the equatorial SCS

S. H. Ooi et al.

\section{Title Page}

Abstract

Introduction

Conclusions

References

Tables

Figures

$1<$

$>1$

4

Back

Close

\section{Full Screen / Esc}

Printer-friendly Version

Interactive Discussion
Fig. 8. Anomalies during El Niño years of (a) mean sea level pressure, (b) sea surface wind, (c) sea surface current and (d) precipitation in December. 

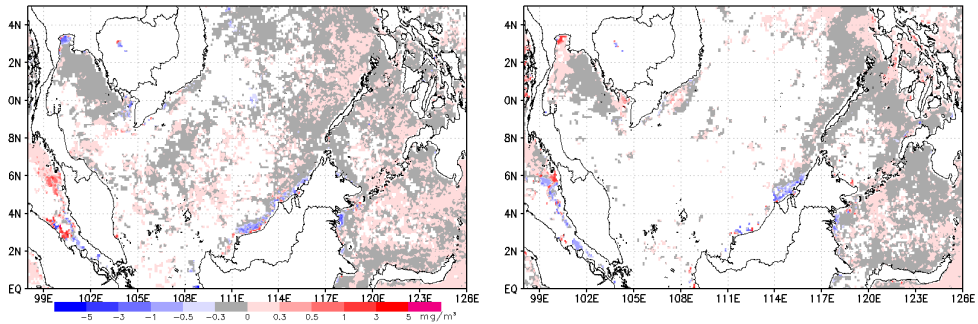

(a)
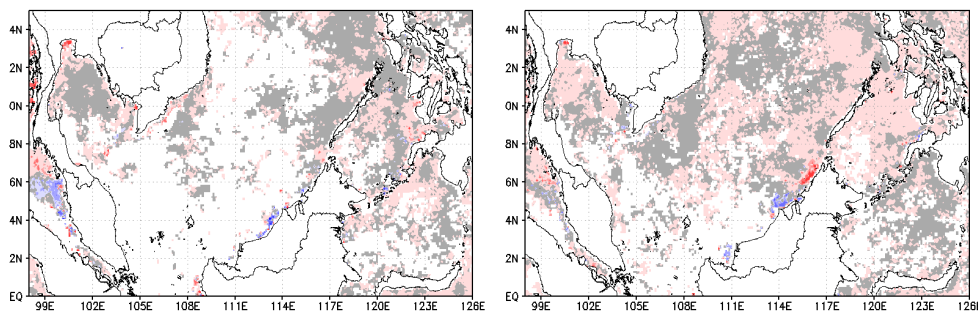

(c)

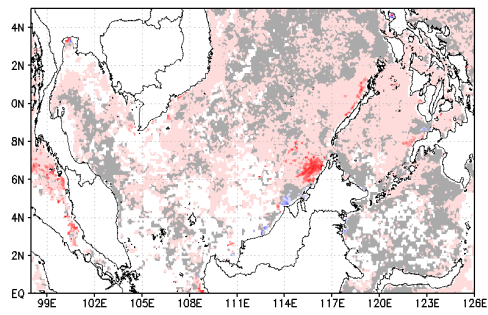

(e)

Fig. 9. Anomalies during El Niño years of chlorophyll a concentration in (a) November, (b) December, (c) January, (d) February and (e) March.

ACPD

13, 21573-21608, 2013

Primary productivity and its variability in the equatorial SCS

S. H. Ooi et al.

Title Page

Abstract

Introduction

Conclusions

References

Tables

Figures

14

$>1$

4

Back

Close

\section{Full Screen / Esc}

Printer-friendly Version

Interactive Discussion 


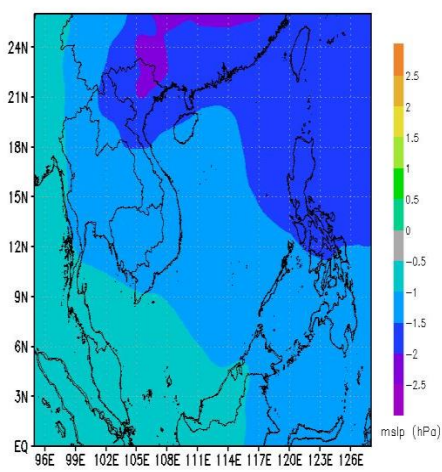

(a)

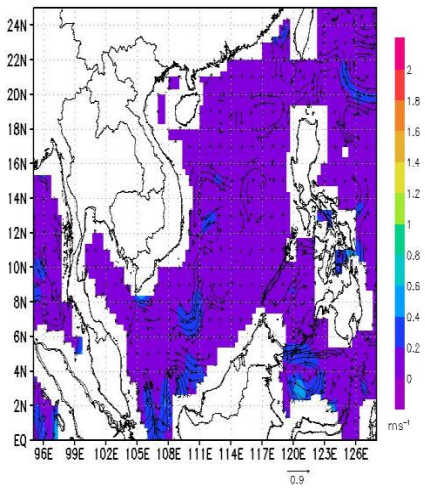

(c)

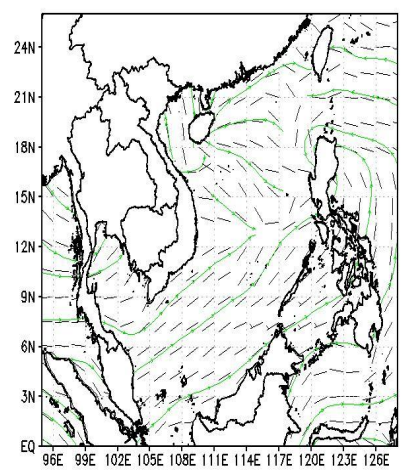

(b)

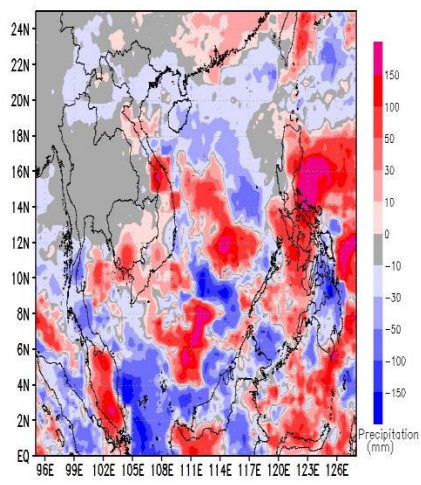

(d)

Fig. 10. Anomalies during La Niña years of (a) mean sea level pressure, (b) sea surface wind, (c) sea surface current and (d) precipitation in December.

ACPD

13, 21573-21608, 2013

Primary productivity and its variability in the equatorial SCS

S. H. Ooi et al.

\section{Title Page}

$1<$

4

\section{Full Screen / Esc}

Printer-friendly Version

Interactive Discussion 


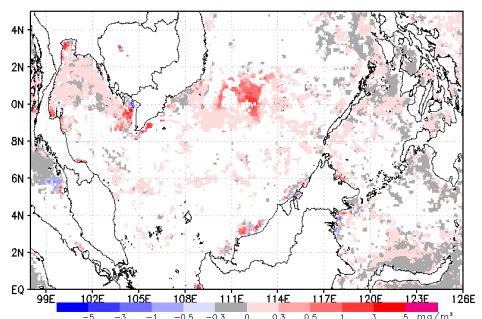

(a)

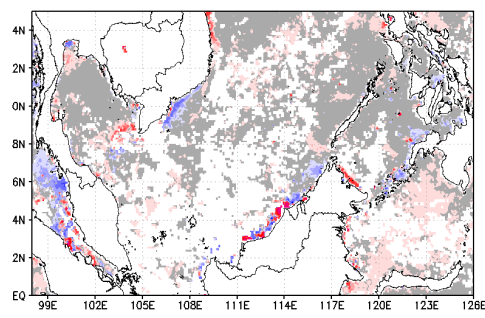

(c)
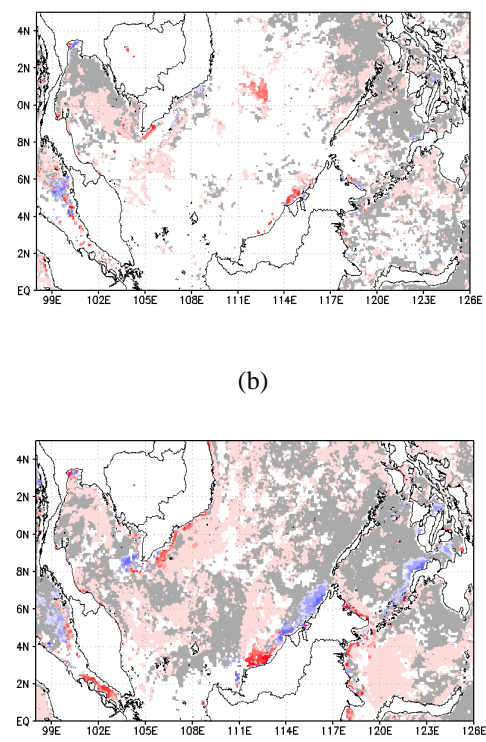

(b)

(d)

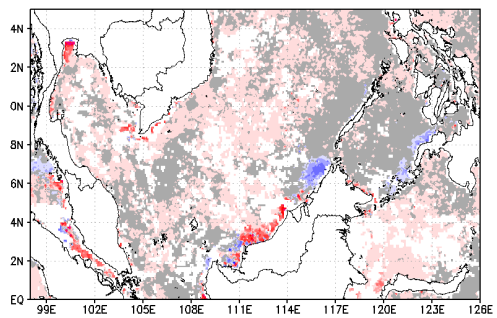

(e)

Fig. 11. Anomalies during La Niña years of chlorophyll a concentration in (a) November, (b) December, (c) January, (d) February and (e) March.

ACPD

13, 21573-21608, 2013

Primary productivity and its variability in the equatorial SCS

S. H. Ooi et al.

\section{Title Page}

Abstract

Introduction

Conclusions

References

Tables

Figures

14

$>1$

4

Back

$>$

Close

\section{Full Screen / Esc}

Printer-friendly Version

Interactive Discussion 


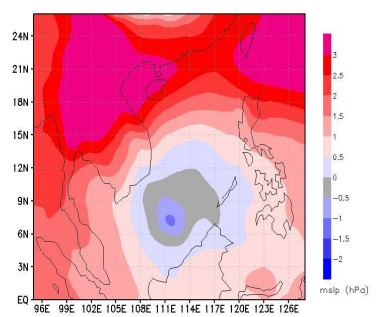

(a)

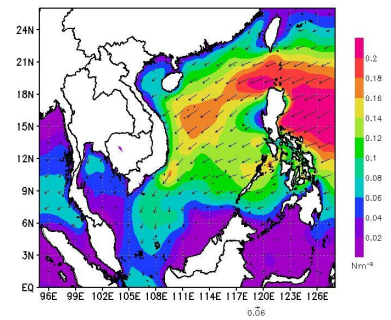

(c)

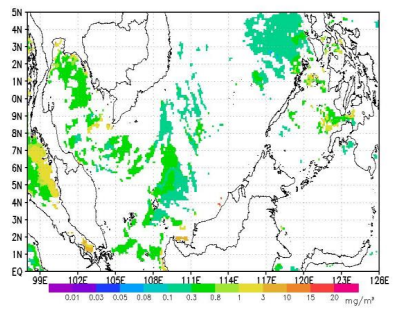

(e)

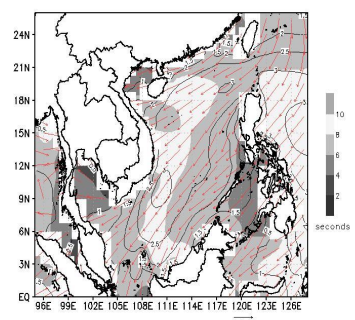

(b)

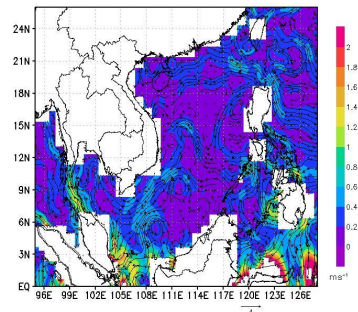

(d)

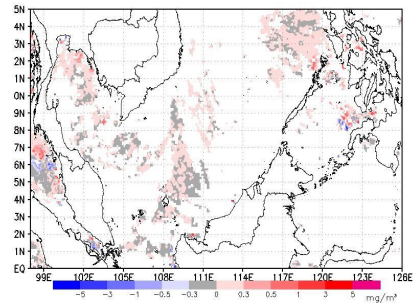

(f)

\section{ACPD}

13, 21573-21608, 2013

Primary productivity and its variability in the equatorial SCS

S. H. Ooi et al.

\section{Title Page}

Abstract

Introduction

Conclusions

References

Tables

Figures

14

$>1$

4

Back

$>$

Close

\section{Full Screen / Esc}

Printer-friendly Version

Interactive Discussion

Fig. 12. (a) Anomaly of mean sea level pressure ( $\mathrm{hPa}$ ), (b) average surface wave (vector with period (s) shaded and height/swell (m) contoured), (c) average sea surface wind stress $\left(\mathrm{Nm}^{-1}\right)$, (d) average sea surface current $\left(\mathrm{m} \mathrm{s}^{-1}\right),(e)$ average and (f) and anomaly of chlorophyll a concentration $\left(\mathrm{mg} \mathrm{m}^{-3}\right)$ during the period 16-20 January 2010. 


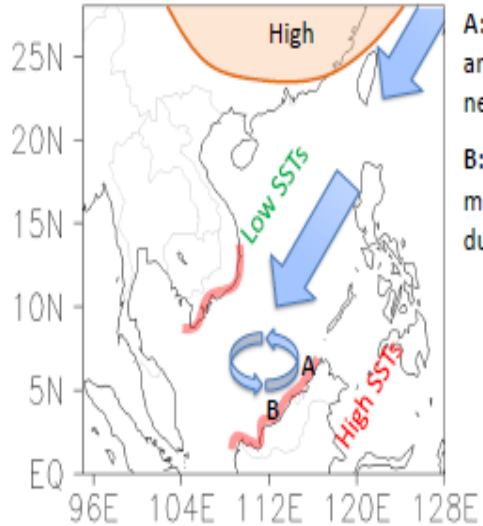

A: late monsoon season, positive chlorophyll-a anomaly during El Nino; late monsoon season, negative chlorophyll-a anomaly during La Nina

B: no chlorophyll-a anomaly during El Nino; late monsoon season, positive chlorophyll-a anomaly during La Nina

\begin{tabular}{|l|c|c|c|}
\hline ENSO & Cold surges & Ca Reg. A & Ca Reg. B \\
\hline La Nina & + & - & + \\
\hline El Nino & - & + & 0 \\
\hline
\end{tabular}

Red: Coastal areas with most pronounced annual cycle in chlorophyll-a concentrations. Blue: Dominant circulation patterns in the SCS; Cold Surge (arrow) and Borneo Vortex (circle).

Fig. 13. A schematic diagram showing the impacts of ENSO on variabilities of chlorophyll a concentrations.
ACPD

13, 21573-21608, 2013

Primary productivity and its variability in the equatorial SCS

S. H. Ooi et al.

\section{Title Page}

Abstract

Introduction

Conclusions

References

Tables

Figures

14

$\rightarrow 1$

4

Back

$\checkmark$

Close

Full Screen / Esc

Printer-friendly Version

Interactive Discussion 